\title{
EMPIRICAL ANALYSIS OF MERCHANDISE TRADE DEFICIT AND THE CURRENT ACCOUNT: LEBANON
}

\author{
S. A. Azar*1, A. Bolbol' ${ }^{2}$, H. Hakimian ${ }^{3}$, A. Mouradian ${ }^{4}$ \\ ${ }^{1}$ Faculty of Business Administration \& Economics, Haigazian University, Beirut, \\ Lebanon. \\ ${ }^{2}$ BLOM Bank, Beirut, Lebanon. \\ ${ }^{3}$ Council of Development and Reconstruction, Beirut, Lebanon \\ ${ }^{4}$ BLOMINVEST Bank, Beirut, Lebanon. \\ Corresponding author: Samih Azar \\ samih.azar@haigazian.edu.lb
}

(Received February 2018 - Accepted March 2019)

\begin{abstract}
S. A. Azar, A. Bolbol, H. Hakimian and A. Mouradian. 2019. Empirical analysis of merchandise trade deficit and the current account: Lebanon. Lebanese Science Journal. 20(1): 173-192.

The paper provides an empirical analysis of Lebanon's merchandise trade deficit and the current account for the 1969-2016 period. Using the Auto-Regressive Distributed Lag approach, it estimates standard demand functions for merchandise exports and imports and the trade deficit. The results show that real exchange rates do not have a long-run impact on exports, imports, the trade deficit, and the current account; domestic production has a notable effect on reducing trade deficits while absorption expenditures, primarily public expenditures, have a strong effect on increasing trade deficits. The main three conclusions and policy implications that emerge from the analysis are: first, the Central Bank of Lebanon's policy of fixing the exchange rate in the post-war period has not harmed competitiveness and has proved to be a strong basis for monetary stability; second, a more active industrial and investment policy is needed to enhance competitiveness and export promotion and to increase and diversify domestic production; and third, public expenditures ought to be urgently rationalized and conducted within a framework of sound fiscal and governance reforms.
\end{abstract}

http://dx.doi.org/10.22453/LSJ-020.1.173-192 National Council for Scientific Research - Lebanon 2018® lsj.cnrs.edu.lb/vol-20-no-1-2019/ 
Keywords: trade deficit, current account, ARDL and ECM estimation, short and long run, Lebanon.

\section{INTRODUCTION}

For a small open economy that is characterized by a long history of mercantile and entrepreneurial activity, Lebanon should be considered an export powerhouse. But, sadly, it is not. As can be seen from table (1), between 2010 and 2016, the ratio of merchandise exports $(\mathrm{X})$ to GDP averaged only $8 \%$, whereas the ratio of merchandise imports (M) to GDP stood at $43 \%$. These compare, respectively, to corresponding averages of $20 \%$ and $19 \%$ to middle income countries - in other words, Lebanon's export capacity is less than half of its representative income group, while its import capacity is more than twice as much. Not surprisingly, Lebanon's trade deficit (TD) to GDP ratio averaged 34\% during that period, against a current account deficit (CAD) of $21 \%$. Remittances, mostly, helped shrink the gap between these two ratios by $13 \%$, but the resulting current account deficits mean that Lebanon has to continuously attract capital inflows to evade balance of payments deficits and any cracks to its exchange rate peg. ${ }^{1}$ This is a tall order for most countries, let alone for a country that has been plagued with political setbacks since at least $1975 .^{2}$ It is not that things have been better in periods other than 2010-2016, for as table (1) shows, throughout the 1969-2016 period the TD to GDP ratio averaged 44\% while that of CAD to GDP $14 \%$. In fact, the country had been in trade deficit in each year of the 1969-2016 period and in current account deficit in all years except 1976 and $1982 .^{3}$

It is apparent that Lebanon's external performance and its dependence on foreign resource inflows run the risk of unsustainability, especially at times when the Central Bank can't maintain adequate foreign reserves and guarantee the stability of the exchange rate. It is also evident that the first and best thing to do so as to rectify such imbalances is to improve the country's trade performance. And this requires a thorough understanding of what determines the trade account in Lebanon: is it mostly real factors and industrial policy? Is it monetary factors and exchange rate policy? Or is it expenditure factors and fiscal policy? The aim of this short paper is to shed light on answers to these queries by estimating the determinants of trade and current accounts in Lebanon for both the short run and long run; and propose tentative policy suggestions on how to improve external imbalances. It is our belief that this is the first time such an investigation is undertaken for Lebanon, or at least for its post-war economy. 
Table 1. Lebanon: Merchandise Trade and the Current Account: Averages for the 1969-2016 Period and Sub-Periods. (Source: Central Bank of Lebanon (BdL); International Monetary Fund; and World Bank).

\begin{tabular}{|c|c|c|c|c|c|c|c|c|}
\hline Indicators & \multicolumn{4}{|c|}{ \$Billion } & \multicolumn{3}{|c|}{$\%$} \\
\hline Periods & X & M & TD & CAD & X/GDP & M/GDP & TD/GDP & CAD/GDP \\
\hline $\mathbf{1 9 6 9 - 1 9 7 4}$ & 0.56 & 1.21 & 0.65 & 0.06 & 23 & 54 & 31 & 2 \\
\hline $\mathbf{1 9 7 5 - 1 9 8 1}$ & 0.89 & 2.66 & 1.78 & 0.19 & 30 & 83 & 53 & 4 \\
\hline $\mathbf{1 9 8 2 - 1 9 9 0}$ & 0.61 & 2.6 & 1.99 & 0.52 & 19 & 81 & 62 & 15 \\
\hline $\mathbf{1 9 9 1 - 2 0 1 0}$ & 1.53 & 8.54 & 7.02 & 2.95 & 8 & 50 & 42 & 19 \\
\hline $\mathbf{2 0 1 1 - 2 0 1 6}$ & 3.65 & 19.99 & 16.34 & 10.05 & 8 & 43 & 34 & 21 \\
\hline $\mathbf{1 9 6 9 - 2 0 1 6}$ & 1.41 & 7.08 & 5.68 & 2.62 & 18 & 62 & 44 & 14 \\
\hline
\end{tabular}

We will structure the paper as follows. Section 2 will present standard demand functions for merchandise exports and imports and the trade deficit, but with the innovation of including absorption expenditures in the import demand function to suit the Lebanese situation. We will also provide a novel presentation of the current account function based on the balance of payments identity. Section 3 will report on the econometric results, which involve estimating the functions using the Auto-Regressive Distributed Lag and Cointegration methodologies for the period running from 1969 to 2016. Section 4 will evaluate the results, the most important of which is that real exchange rates do not have a long-run impact on exports, imports, the trade deficit, and the current account; that real exchange rates have paradoxical effects on imports and exports in the Lebanese context coupled with the failure of the Marshall-Lerner condition to hold in the short run; that, in both the short run and long run, domestic production has a notable effect on reducing trade deficits while absorption expenditures, primarily public expenditures, have a strong effect on increasing trade deficits. Section 5 will delve on the robustness of the results. Two robustness tests are carried out. The first is whether considering the real effective exchange rate as non-stationary, instead of treating it as a stationary process, affects materially the results. The second is to check whether the cointegration tests in this paper, based on the ARDL procedure, provide the same results as the Johansen cointegration tests (Johansen, 1991, 1995; Johansen and Juselius, 1990), in cases where the real effective exchange rate is considered as nonstationary. The last section concludes.

The main three conclusions and policy implications that emerge from the analysis are: first, the Central Bank of Lebanon's policy of fixing the exchange rate in the post-war period has not harmed competitiveness and has proved to be a strong basis for monetary stability; second, a more active industrial and investment policy is needed to enhance competitiveness and export promotion and to increase and diversify 
domestic production; and third, public expenditures ought to be urgently rationalized and conducted within a framework of sound fiscal and governance reforms. The onus, then, is mostly on real-sector policies that have both expenditure-switching and expenditure-changing dimensions. In consequence, all three policy recommendations should help in reversing the trends in the trade deficit and the current account and put them on a sustainable path.

\section{MATERIALS AND METHODS}

We will start with formulating first the merchandise exports, imports, and trade account functions, and then move on to formulate the current account function. Standard neoclassical microeconomic theory postulates demand functions to be dependent on prices and income or expenditures. For merchandise exports demand, this can be expressed as:

$$
X=f(R E E R, Y f)
$$

Where REER is the real effective exchange rate, expressed as eP/P*, with e representing the nominal exchange rate or the price of unit of Lebanese Pound (LBP) in terms of foreign currency, $\mathrm{P}$ the Lebanese price level, and $\mathrm{P}^{*}$ the foreign price level. Note that this interpretation of REER implies that a higher REER is equivalent to a real appreciation. The variable $\mathrm{Yf}$ is foreign income, and is the weighted average of the income of Lebanon's major trading partners. ${ }^{4}$ A priori, we expect REER to have a negative relation with $\mathrm{X}$ since a real appreciation or higher REER will increase the price of Lebanese exports in terms of foreign currency and consequently foreign demand for exports will fall. As to the relation between Yf and $\mathrm{X}$, it is definitely positive unless Lebanese exports are inferior goods.

In the case of merchandise imports we will depart slightly from standard formulations and express Lebanese merchandise imports demand as the following:

$$
M=f(R E E R, G D P, A B S)
$$

Where REER is as defined previously; GDP is of course gross domestic product; and ABS is absorption or private and public expenditures. ${ }^{5}$ The latter is particularly relevant to Lebanon because of the high absorption levels, especially by the public sector which in 2016 ran a deficit to GDP ratio of $9.6 \%$ and a debt to GDP ratio of $148 \%$. Again a priori, we expect REER to have a positive relation with M since a lower REER or a real depreciation increases the price of imports in terms of Lebanese pound and hence leads to lower demand for imports. Also, we expect GDP to have a negative 
relation with $\mathrm{M}$ given that a higher GDP increases the production of domestic goods which displaces the need for imports. Lastly, as to ABS, it surely has a positive relation with $\mathrm{M}$ as higher expenditures involve more demand for imports.

The merchandise trade account is of course the difference between $\mathrm{M}$ and $\mathrm{X}$, and given that Lebanon had been in deficit all through the 1969-2016 period, we will denote the trade account as the trade deficit TD. From equations (1) and (2), TD can be formulated as:

$$
T D=f(R E E R, Y f, G D P, A B S)
$$

Given the a priori relations outlined above for equations (1) and (2), we expect REER and ABS to have a positive relation with TD, in the sense that a higher REER (a real appreciation) and higher $\mathrm{ABS}$ will increase the trade deficit. Alternatively, we expect GDP and Yf to have a negative relation with TD, meaning that larger domestic production and larger foreign demand will reduce the trade deficit.

What does the empirical record have to say on the sign of the trade determinants? There are almost no controversies regarding the sign of coefficients for Yf, GDP, and ABS - they all largely come as expected. However, controversies exist concerning the coefficients for REER - usually expressed as elasticities by estimating the equations using a logarithmic form. But even here there seems to be a convergence towards a few basic findings: income elasticities are larger than price (or exchange rate) elasticities; elasticities of import demand are larger than export demand; price elasticities are larger for lower income countries, disaggregated sectors, initial trade deficits, and the further away real exchange rates are from equilibrium rates. ${ }^{6}$ Another crucial finding is that price elasticities are larger in the long run than in the short run. This, of course, gives validity to the Marshall-Lerner (M-L) condition, which states that depreciation in real exchange rates will improve the trade balance if the absolute sum of the long-run price elasticities of imports and exports exceeds unity. ${ }^{7}$

We proceed now to formulate the functional form for the current account. We will depart from tradition here and express it using a novel, simple framework. Usually, the current account is modeled either using an intertemporal approach, or as function of fundamental macroeconomic determinants, or as the difference between national savings and investment. ${ }^{8}$ We start from the current account identity in the balance of payments, and express accordingly the current account $\mathrm{CA}$ as:

$$
\mathrm{CA}=T B+r N F A+N T
$$


Where TB is the trade balance on goods and services, $r$ is the international interest rate and NFA is net foreign assets making rNFA as interest income generated on NFA, and NT is net transfers including public (grants) and private (remittances) transfers. Note that TB is determined by equation (3), $r$ is exogenously given by international capital markets (as yield on 10-year US government bonds), and NFA is historically pre-determined. This leaves us with net transfers NT, which in fact is dependent on weighted foreign income $Y f: N T=f(Y f)$. Thus the current account CA assumes the following functional form:

$$
C A=f(R E E R, Y f, G D P, A B S, r, N F A)
$$

Similarly, we can postulate a priori the sign of the relations between the CA function and its independent variables. As a result, we expect: a negative relation with REER and ABS, which implies that appreciation in real effective exchange rates and higher expenditures worsen the current account; and a positive relation with Yf, GDP, $r$, and NFA, which indicates that higher foreign income, larger productive capacity, higher international interest rates, and more accumulation of net foreign assets improve the current account. Empirically, in general, there seems to be only uncertainties regarding the sign of the REER coefficient, largely for reasons discussed earlier. ${ }^{9}$

\section{RESULTS}

We estimated equations (1)-(3) and (5) for the annual period stretching from 1969 to 2016 because we wanted to include the pre-war period (prior to 1975) as far back as data availability permits. The data sources for all variables are listed in Appendix B.

In order to subject the data to econometric analysis, it is crucial to determine first whether the variables follow a stationary probability distribution, i.e. whether they have a constant variance and a constant mean to which they converge and revert in the long run. This ensures that statistical relations do not turn out to be spurious. Unit root tests are therefore necessary. The unit root test that is selected is the Elliott-RothenbergStock (ERS) point-optimal test. All variables are found to be non-stationary in log levels except the real effective exchange rate REER, which behaves as a stationary process. This applies to the log levels of weighted foreign income Yf, domestic output GDP, merchandise exports $\mathrm{X}$ and imports $\mathrm{M}$, absorption ABS, the trade deficit TD, and the current account CA, all measured in units of US dollars. ${ }^{10}$ For this reason, REER will be treated as a non-dynamic, fixed regressor. This amounts to including it in all shortrun regressions, and omitting it from long-run regressions. What this implies is that the impact of the real effective exchange rate on exports, imports, the trade deficit, and the 
current account balance is ephemeral, lasting no more than one year, which is the frequency of the data. In order to check the robustness of the unit root tests, the Augmented Dickey-Fuller (ADF) test is applied. The same variables as above are found to be non-stationary, with the minimum actual p-value at 0.0754 . In contrast the log of the REER is found also to be non-stationary, with an actual p-value of 0.0754. Since unit root tests have usually low power, it is decided to consider that the log of the REER is stationary. The maximum $\mathrm{p}$-value for the differenced series is 0.0041 , strongly rejecting non-stationary processes. The details of these unit root tests (ERS and ADF) are available from the authors upon request.

The long-run and short-run regressions are estimated by the Autoregressive Distributed Lag (ARDL) procedure. We begin with merchandise exports or equation (1), in terms of logs, whose results are reported in table (2).

Table 2. Merchandise exports function.

\title{
NO LONG RUN RELATION \\ SHORT RUN RELATION: ARDL ERROR CORRECTION REGRESSION
}

\author{
DEPENDENT VARIABLE: $\Delta(\operatorname{LOG}(\mathrm{X}))$ \\ SAMPLE: 1969-2016 \\ INCLUDED OBSERVATIONS: 47 \\ FIXED REGRESSOR: LOG(REER) \\ DYNAMIC REGRESSOR: LOG(YF) \\ NUMBER OF MODELS EVALUATED: 20 \\ SELECTED MODEL: ARDL $(1,1)$ \\ HAC STANDARD ERRORS AND COVARIANCE
}

\begin{tabular}{llll} 
VARIABLE & COEFFICIENT & T-STATISTIC & P-VALUE \\
$\Delta($ LOG $(Y f))$ & 1.721964 & 4.132203 & 0.0002 \\
$(L O G(R E E R))$ & 0.242071 & 2.733194 & 0.0091 \\
COINT $(-1)$ & -0.124805 & -2.801391 & 0.0077 \\
\multicolumn{4}{c}{ ADJUSTED R - SQUARE: 0.264744 } \\
BREUSCH - GODFREY SERIAL CORRELATION TEST: PROB. F $(3,39)=0.4349$ \\
\multicolumn{3}{c}{ SCHWARZ CRITERION: - 0.102150 } \\
ADJUSTMENT TO THE LONG RUN: 8.0125 YEARS
\end{tabular}


The number of models evaluated by the statistical package is 20 , and the resulting optimal specification is ARDL $(1,1)$. The Schwarz information criterion is minimized because it provides for more parsimonious models than the competing Akaike information criterion. The standard errors and covariance are robust utilizing the Newey-West HAC adjustment, although there is little evidence of both serial correlation of the residuals and residual heteroscedasticity. Noteworthy is that all these restrictions are implemented in the four estimated equations. One particularity of the results is that the F-bounds test rejects cointegration of the two non-stationary variables, foreign income and exports. Cointegration, of course, is another term for a long-run relation, whereby two non-stationary variables do not drift apart or diverge from each other too much in the long run despite their non-stationarity.

The short-run results, however, are highly significant statistically. They show that a $1 \%$ increase in foreign income increases exports by $1.722 \%$. Also, the elasticity with respect to REER is 0.242 , meaning that a $1 \%$ appreciation of the real effective exchange rate increases exports by $0.242 \%$. This is a paradoxical result and not a sign that we would expect a priori. The Durbin-Watson statistic is a healthy 1.765630 . Higher-order serial correlation is absent as tested by the Breusch-Godfrey LM test for three lags. One weak result is that the short-run disequilibrium is eliminated at a rate of $12.5 \%$ a year, and that it takes around 8 years for full adjustment to be over. Another weak econometric diagnostic is the adjusted R-Square which stands at a low level of $26.4744 \%$.

Table (3) presents the results of estimating the ARDL procedure for the log of merchandise imports. There is no long run relation as evidenced by the F-bounds test. The adjustment is complete in 4.5 years. Moreover, the Durbin-Watson statistic is not problematic, being 2.13437, and higher-order serial correlation is absent as tested by the Breusch-Godfrey LM test for three lags. The ARDL procedure, after 100 model evaluations, chooses a specification of ARDL $(1,2,1)$. The effect of GDP or domestic output is negative and has a net intermediate elasticity of -1.229 . The t-statistics for GDP and its lag are respectively -9.54 and 2.64. However, the effect of absorption ABS is more significant, both in magnitude and in sign. The elasticity of imports with respect to absorption is 2.2412 , with a t-statistic of 16.37146: a $1 \%$ increase in absorption induces a $2.2412 \%$ increase in imports. The real effective exchange rate has an elasticity of -0.0369 , with a t-statistic of -4.028 , which implies that a $1 \%$ appreciation of the real exchange rate reduces imports by $0.037 \%$. Though this is quite a small effect, its sign however is paradoxical. Tables (2) and (3) imply that the Marshall-Lerner condition is not satisfied in the short-run since the absolute sum of the price elasticities of imports and exports is only 0.278 (less than 1). Worth mentioning also is the very high adjusted $\mathrm{R}-$ Square of the import function that reaches around $95 \%$. 
Table 3. Merchandise imports function.

\title{
NO LONG RUN RELATION \\ SHORT RUN RELATION: ARDL ERROR CORRECTION REGRESSION
}

\author{
DEPENDENT VARIABLE: $\triangle(\log (M))$ \\ SAMPLE: 1969-2016 \\ INCLUDED OBSERVATIONS: 47 \\ FIXED REGRESSOR: LOG (REER) \\ DYNAMIC REGRESSORS: LOG(GDP), LOG (ABS) \\ NUMBER OF MODELS EVALUATED: 100 \\ SELECTED MODEL: ARDL $(1,2,1)$ \\ HAC STANDARD ERRORS AND COVARIANCE
}

\begin{tabular}{|c|c|c|c|}
\hline VARIABLE & COEFFICIENT & T-STATISTIC & P-VALUE \\
\hline$\Delta(\mathrm{LOG}(G D P))$ & -1.336223 & -9.535886 & 0.0000 \\
\hline$\Delta(\operatorname{LOG}[G D P(-1)])$ & 0.107196 & 2.641443 & 0.0119 \\
\hline$L O G(R E E R)$ & -0.036869 & -4.027968 & 0.0003 \\
\hline$\Delta(\mathrm{LOG}(A B S))$ & 2.241241 & 16.37146 & 0.0000 \\
\hline COINT $(-1)$ & -0.220996 & -3.951324 & 0.0003 \\
\hline \multicolumn{4}{|c|}{ Adjusted $R-$ square: 0.945861} \\
\hline \multicolumn{4}{|c|}{$\begin{array}{c}\text { Breusch - Godfrey serial correlation test: Prob. } F(3,35)=0.2135 \\
\text { Schwarz criterion: }-2.540651 \\
\text { ADJUSTMENT TO THE LONG RUN: } 4.525 \text { YEARS }\end{array}$} \\
\hline
\end{tabular}

The econometric results of the log of the trade deficit are reported in table (4). The number of regressions evaluated is 500, and the ARDL specification is $(1,0,0,1)$. Interestingly, a long-run relationship exists according to the F-bounds test. While GDP and ABS enter statistically significantly in this relationship, the coefficient on the Yf variable is statistically marginally significant with a t-statistic of 1.8543 , and at 0.0343 it is economically small too. In the long run, a $1 \%$ increase in absorption leads to a $3.006 \%$ increase in the trade deficit with a t-statistic of 37.603. Also, in the long run, a $1 \%$ increase in GDP leads to a $2.006 \%$ fall in the trade deficit, with a t-statistic of 27.792. Equally interesting, in the short run, the effect of absorption is 2.967 , down trivially from the long-run effect of 3.006. However, foreign income Yf and GDP do not enter the short-run regression, and have therefore no short-run effect on the trade deficit. Finally, the short-run effect of REER is paradoxical at -0.0529 with a t-statistic of 27.364 , since a $1 \%$ appreciation of the real effective exchange rate leads to a fall in the trade deficit by $0.0529 \%$, though it is a figure that is economically not too large. Higher- 
order serial correlation is absent as tested by the Breusch-Godfrey LM test for three lags. The adjusted R-Square of the regression is extremely high standing at 0.9913 . Adjustment to the long run takes only 1.07 years, a figure which is surprisingly low but quite decent.

\title{
Table 4. Trade deficit function.
}

\section{LONG RUN RELATION:}

F-BOUNDS TEST: F-STATISTIC=473.2115; CRITICAL F-STATISTIC (1\%): 5.412

$\begin{array}{llll}\text { VARIABLE } & \text { COEFFICIENT } & \text { T-STATISTIC } & \text { P-VALUE } \\ \text { CONSTANT } & -2.222356 & -7.873906 & 0.0000 \\ \text { LOG }(Y f) & 0.034289 & 1.854307 & 0.0711 \\ \text { LOG }(G D P) & -2.008868 & -27.79246 & 0.0000 \\ \text { LOG }(A B S) & 3.005671 & 37.60334 & 0.0000\end{array}$

\section{SHORT RUN RELATION: ARDL ERROR CORRECTION REGRESSION}

\author{
DEPENDENT VARIABLE: $\triangle(\log (T D))$ \\ SAMPLE: 1969-2016 \\ INCLUDED OBSERVATIONS: 47 \\ FIXED REGRESSOR: LOG (REER) \\ DYNAMIC REGRESSORS: LOG $(Y f), L O G(G D P), \operatorname{LOG}(A B S)$ \\ NUMBER OF MODELS EVALUATED: 500 \\ SELECTED MODEL: ARDL $(1,0,0,1)$ \\ HAC STANDARD ERRORS AND COVARIANCE
}

$\begin{array}{llll}\text { VARIABLE } & \text { COEFFICIENT } & \text { T-STATISTIC } & \text { P-VALUE } \\ \Delta(\text { LOG }(A B S)) & 2.966783 & 47.91379 & 0.0000 \\ L O G(R E E R) & -0.052924 & -27.36417 & 0.0000 \\ \text { COINT }(-1) & -0.936071 & -29.00372 & 0.0000\end{array}$

$$
\begin{gathered}
\text { Adjusted } R-\text { square: } 0.991291 \\
\text { durbin }- \text { watson: } 1.645894 \\
\text { Breusch - Godfrey serial correlation test: Prob. F }(3,37)=0.0874 \\
\text { Schwarz criterion: }-4.090987 \\
\text { ADJUSTMENT TO THE LONG RUN: } 1.07 \text { YEARS }
\end{gathered}
$$

Lastly, table (5) shows the empirical findings pertaining to equation (5) of the current account. The current account balance is taken as is (i.e. a deficit is a negative 
number) so logs cannot be utilized. The bounds F-test fails to reject the null hypothesis of no cointegration. Hence, there is no long run relation between the variables. The number of models evaluated by the statistical package is 12,500; and the selected mode is ARDL $(1,0,0,0,0,1)$. Two variables are selected for the short-run error-correction model: the non-dynamic log of REER and the first difference of the log of NFAVA. The effect of the REER variable is highly significant and positive at 0.9621, though paradoxical. In the short run, the current account balance improves with an appreciation of the real effective exchange rate, almost on a one-to-one basis. The coefficient on NFAVA $^{11}$ is around 2.01 and is statistically significant: happily, when NFAVA increases by $1 \%$ the current account balance strengthens by $2 \%$. The goodness-of-fit for this short-run regression, as measured by the adjusted R-Square, is a mere $31.55 \%$. However, the Durbin-Watson statistic is very close to the neutral value of 2 , being 2.0164 , and this means that the residuals are well-behaved. This is confirmed by the Breusch-Godfrey LM test for three lags. Finally adjustment is complete within 2.12 years, a figure which seems quite reasonable.

Table 5. Current account function.

NO LONG RUN RELATION

SHORT RUN RELATION: ARDL ERROR CORRECTION REGRESSION

DEPENDENT VARIABLE: $\triangle(C A)$

SAMPLE: 1969-2016

INCLUDED OBSERVATIONS: 47

FIXED REGRESSOR: $L O G(R E E R)$

DYNAMIC REGRESSORS: LOG(Yf), LOG(GDP), LOG(ABS), LOG $(r), \operatorname{LOG}(N F A V A)$

NUMBER OF MODELS EVALUATED: 12,500

SELECTED MODEL: $\operatorname{ARDL}(1,0,0,0,0,1)$

HAC STANDARD ERRORS AND COVARIANCE

$\begin{array}{llll}\text { VARIABLE } & \text { COEFFICIENT } & \text { T-STATISTIC } & \text { P-VALUE } \\ \text { LOG }(R E E R) & 0.962158 & 4.435576 & 0.0001 \\ \Delta(\operatorname{LOG}(N F A V A)) & 2.006626 & 2,338919 & 0.0247 \\ \operatorname{COINT}(-1) & -0.472321 & -4.775372 & 0.0000\end{array}$

Adjusted $R$ - square: 0.315447

durbin - watson: 2.016377

Breusch-Godfrey serial correlation test: Prob. $F(3,35)=0.2466$

Schwarz criterion: 3.276788

ADJUSTMENT TO THE LONG RUN: 2.12 YEARS 
The Ramsey RESET test (Ramsey, 1969) was applied on the residuals of all models in order to test for stability of coefficients and good specification. The actual pvalues are $0.1093,0.2578,0.5524,0.1023$ for respectively the export, import, trade, and current account regressions, failing to reject the null hypotheses of stability and good specification. Since the data is time series, heteroscedasticity of the residuals should not be a problem. In fact the Harvey heteroscedasticity tests (Harvey, 1976) fail to reject the nulls of homoscedasticity with actual p-values of $0.6201,0.8152,0.6134$, and 0.0974 for respectively the export, import, trade, and current account models. Finally, normality of residuals was not tested since the Central Limit Theorem can be invoked for asymptotic normality because the sample sizes are relatively large.

\section{DISCUSSION}

Perhaps the most striking result from the above estimation is that real effective exchange rates have no long-run impact on merchandise exports and imports, the trade deficit, and the current account. Clearly, changes in nominal exchange rates do have a short-run or immediate impact on the prices of exports and imports, but they will also set in motion domestic cost and price dynamics that will counter the initial changes in nominal exchange rates and render real exchange rates unchanged in the long-run. ${ }^{12}$ What this implies is that any talk about Lebanon's real exchange rates being overvalued and with detrimental effects on the country's trade performance is not valid. It also means that the Central Bank's policy of pegging officially the nominal exchange to the US dollar in 1997 has not hurt the country's competitiveness in the long run. In all likelihood, it has benefited extremely the country as a nominal anchor for monetary and exchange rate stability. ${ }^{13}$

Another interesting result in the context of REER is its paradoxical effects on $\mathrm{X}$ and $\mathrm{M}$ in the short run: an appreciation in the real effective exchange rate will increase merchandise exports and reduce merchandise imports. For exports, this could be explained by the fact that an appreciation in REER will drive Lebanese exporters to increase the US dollar price of their exports and earn consequently a higher value for their exports as measured in US dollars. The purpose of this pricing-to-market policy is to maintain the same value of their exports as measured in Lebanese pounds. For imports, the negative sign of the coefficient is hard to explain, but thankfully it is quite small at -0.036. Thankfully also, a negative relation is maintained in the short run between REER and the trade deficit and a positive one with the current account meaning that an appreciation in the real exchange rate would have reduced the trade deficit and improved the current account. More important, this would mean that any presumed overvaluation in Lebanese real exchange rates would have helped the trade and current accounts instead of harming them. ${ }^{14}$ This somehow paradoxical result for 
Lebanon also justifies the anomalous result of obtaining the higher price elasticity of exports at 0.242 than the price elasticity of imports at -0.036 , in contrast to other countries.

Lebanon, however, remains in conformity with the international evidence in having its short-run income and output elasticities larger than its price elasticities: the foreign income elasticity of exports stood at 1.721 and the domestic output elasticity of imports at -1.336 . The strong and positive effect of foreign income implies that exports are very sensitive to foreign demand and more liable to foreign shocks. This calls for a dynamic commercial policy, aiming towards more diversification of export markets through additional trade agreements and even membership in the WTO. It also calls for more facilitation of export routes so as to have faster and wider access to regional and international markets. But, more importantly, it requires a more active industrial and competitiveness policy that is sector-specific and that aims at nurturing comparative advantage in various products. There is evidence that, despite the absence of such a strategy, Lebanon was regaining its export sophistication by around 2010 when hightech exports were $13.8 \%$ of total exports but fell soundly to $2.1 \%$ in $2016 .{ }^{15}$ That the export sector could initiate such revival on its own was remarkable, so imagine what it would be like if a credible competitiveness policy is followed. No doubt, the outcome would help transform Lebanon into an aspiring export-oriented economy.

As interesting is the negative and decent effect of domestic output on imports. This crucial result signifies the importance of expanding and diversifying domestic production to increase aggregate supply in the economy and to replace imports accordingly. Perhaps more importantly, increasing the size of the economy is not only desirable but also feasible. The various political shocks that Lebanon has been through over the past four decades have left the economy operating way below its productive capacity. As a result, Lebanon's potential real GDP or output growth stands at more than $6 \%$ with the prospect of equal contributions from labor, capital, and technology. ${ }^{16}$ So real sector policies that enhance the investment climate and reduce the risk and cost of doing business are sorely needed, not just to reduce the reliance on imports but to increase steady growth and employment. Moreover, this effect of domestic output is carried to the long run through its impact on the trade deficit. In fact, this effect is larger than the short-run effect on imports, since the coefficient stands at -2.008 , signifying that positive changes in domestic production will reduce the trade deficit by twice as much in the long run.

Of significant importance is the effect of absorption ABS on both imports and the trade deficit. The positive short-run effect of ABS on imports and the trade deficit is in excess of 2.24 and the positive long-run effect on the trade deficit is 3 -implying that 
higher expenditures will increase the trade deficit permanently by three times as much. Though this effect seems too large in magnitude and makes the trade deficit too sensitive to changes in expenditures, it is nevertheless very relevant qualitatively. This is primarily because of the high public expenditures in Lebanon that caused recurring budget deficits and escalating public debt (especially in the post-war period) whose ratios to GDP rose, respectively, to close to $10 \%$ and to $150 \%$ in 2016 . The usual "suspects" for these inflated expenditures are high interest payments, a bloated wage bill, and rampant "appropriated expenditures" (or corruption), in addition to expenditures that are specific to Lebanon and they are chronic transfers to Electricite du Liban. ${ }^{17}$ Needless to say, shrinking public deficits and debt will ease considerably trade imbalances. This necessitates urgent fiscal and governance reforms besides structural adjustments to fiscal policy that should include reform of public enterprises and even privatization. A final, notable result is the short-run positive effect of NFAVA on the current account with a significant coefficient of 2 . This, of course, is not a very surprisingly result, but its implications are quite essential. They point to the need of maintaining a policy of open and judicious capital account, and a hospitable investment and financial environment to attract capital flows especially of the sticky foreign direct investment variety.

Lastly, it is very important to realize that, with monetary policy sidelined to maintain the fixed exchange rate peg, the burden is on commercial, fiscal, and, most crucially, real-sector reforms to attain external and internal balance through deliberate, effective expenditure-switching and expenditure-changing policies. ${ }^{18}$

\section{Robustness tests}

As already mentioned two robustness tests are carried out. The first is to check whether the results change materially if one assumes that the real effective exchange rate (REER) is non-stationary. It is recalled that the unit root tests were dubious in this regard: the ERS test rejecting non-stationarity while the ADF test failing to reject nonstationarity.

The ARDL procedure applied to the export function finds no long run relation, does not include the REER in the short run ECM regression, and all the coefficients in the ECM short run regression remain the same and have the same standard errors. Therefore there is no material change.

The ARDL procedure applied to the import function finds no long run relation, does not include the REER in the short run ECM regression, and all the coefficients in 
the ECM short run regression remain the same and have the same standard errors. Therefore there is no material change.

The ARDL procedure applied to the trade function finds a long run cointegration relation. All the coefficients in the long run regression remains the same and have the same standard errors. The REER enters the long run regression with a statistically significant negative coefficient that has also the wrong sign (-0.0565). The REER does not enter the short run ECM regression and all coefficients in this ECM regression remain the same with the same standard errors.

The ARDL procedure applied to the current account model does not find a long run cointegration relation, does not include the REER in the short run ECM regression, and the lagged cointegration residual has the same coefficient and statistical significance, while the coefficient on the change of the log of the NFA variable in the ECM short run regression changes materially from 2.007 to 0.676 but turns out to be statistically insignificant.

Therefore it can be concluded that whether the log of the REER is considered to be stationary or non-stationary does not materially affect the results, and, in most cases, keeps the other coefficients the same with the same standard errors.

The second robustness test is to test whether the presence of cointegtration, or its absence, depends on the statistical methodology adopted. It is recalled that the procedure that was applied is the ARDL one. What happens if the Johansen procedure is applied instead? For this purpose the REER variable will be considered to be nonstationary.

The Johansen procedure finds no stochastic trends for the export function. The trace test and the maximum Eigen value test have both high p-values. This is in conformity to the ARDL test results. Also, the Johansen procedure finds no stochastic trends for the import function. The trace test and the maximum Eigen value test have both high p-values. This is in conformity to the ARDL test results. There is mixed evidence on the current account model: the trace test finding one stochastic trend with a p-value of 0.0051, thus rejecting no-cointegration, while the maximum Eigenvalue finding no stochastic trends at all, thus supporting no-cointegration. It is recalled that the ARDL test finds in this regard an absence of cointegration. There is also mixed evidence on the trade function: the trace test finding one stochastic trend with a p-value of 0.0452 , thus rejecting no-cointegration, while the maximum Eigenvalue finds no stochastic trends at all, thus supporting no-cointegration. It is recalled that the ARDL test finds in this regard the presence of cointegration. Overall there is mixed evidence 
on this general robustness test. It is noteworthy to mention that the two cointegration tests, ARDL and Johansen, are based on two different specifications of the underlying model. The Johansen test assumes the same lag length for all variables while the ARDL test selects the best lag length for each variable.

\section{CONCLUSION}

The short paper highlights the chronic deficiency in Lebanon's trade and current account imbalances over the course of its contemporary history, and tries to explore potential remedies to alleviate the associated opportunity cost on economic activity by analyzing the driving forces behind the deficits.

Whereas remittances and inflows have become the economy's "lender of last resort", their probable unsustainability has come to light in the wake of the Syrian conflict since 2011 and more recently with the resignation of the Prime Minister in November 2017. In both instances, the Central Bank of Lebanon's (BdL) resources have been unnecessarily constrained, at a time when our analysis reveals that BdL's policy of pegging the currency has been at the forefront of monetary stability, in addition to being a pillar of confidence for the economy. Not to mention, of course, BdL's continuous input in stimulating economic activity through alternative business schemes such as incentivizing knowledge startups.

With debt-servicing interest payments and transfers to the public electricity utility, Electricite du Liban, making up almost $50 \%$ of overall government expenditures, it is apparent that they represent gaping holes in the deficit and hence call for the need for fiscal policy to be redressed. Also, despite the fact that Lebanon's political fragmentation has now become part of a new "normal", the government needs to pursue a reform agenda aimed ultimately at stimulating the private sector. The starting point is building the institutional and technical capacities of the government. More specifically, government entities should relieve the excess burden on BdL and should assume their full responsibilities in terms of designing and executing reforms. In addition, capital investments in infrastructure are badly needed, so as telecommunication, transport, and electricity networks are brought up to international standards. As important, the business environment ought to become more conducive to facilitating businesses, including partnerships between the private and public sectors. Lebanon's World Bank rank of 133 out of 189 in Doing Business Report does not bode well with global norms and should be improved by cutting down on red tape and corruption.

It is only after tackling these structural problems that the government can ensure the success of its reform model by prioritizing real sector policies at the core of which is 
promoting export-driven industries. One crucial aspect of the productivity of a nation can be measured by its balance of payments position, where exports play a pivotal role in shoring up foreign reserves rather than depending on outside resources that have proven their fragility amidst the difficult geopolitical climate of the region. Moreover, diversifying the industrial sector through new domestic and foreign investments will enhance competitiveness and bring more equilibrium and stability to the economy in the face of ever existing challenges. On a final note, establishing such an environment will also reverse the "brain drain" effect by offering the future generation the hope to become productive in their homeland rather than migrate, perhaps for good, to overseas economies.

\section{ENDNOTES}

1. Between 2010 and 2016, labor remittances averaged more than $\$ 7.5$ billion annually. This perhaps makes Lebanon a "rentier" economy, in the thrall of a "resource curse" without even the presence of oil and gas wealth!

2. The main political upheavals were: the civil war from 1975 to 1990; the Israeli invasion in 1982; the assassination of Prime Minister Hariri in 2005; another Israeli invasion in 2006; and the Syrian crisis (still ongoing) and the "Arab Spring" in 2011.

3. Of course, developing countries have to incur current account deficits because of their development needs, but in Lebanon they have consistently been too big and too frequent.

4. The weights are distributed as follows: 50\% for Arab countries; $30 \%$ for European countries; $10 \%$ for North American countries; and $10 \%$ for African countries.

5. In terms of national income accounting, domestic output minus absorption is equal to the trade balance in goods and services; and national income minus absorption is equal to the current account balance. Absorption, in other words, is equivalent to public and private expenditures on investment and consumption.

6. See Senhadji and Montenegro (1999); IMF (2006); and Ketenci (2014).

7. The classical paper on the M-L condition is Houthakker and Magee (1969). It is usually expressed in terms of nominal exchange rates, so we derive in Appendix A the condition in the context of real exchange rates.

8. See Obstfeld and Rogoff (1995) on the intertemporal approach; Blanchard and Giavazzi (2002) on macro determinants; Brissimis et al (2010) and Azar et al (2018) on savings and investment.

9. $\quad$ See Brissimis et al (2010) and Das (2016).

10. We depart from the traditional focus of denominating variables in domestic currency because the Lebanese economy is highly dollarized - close to $70 \%$ of bank deposits and loans are in US dollars - and because this reflects more adequately external vulnerability; see IMF (2006). 
11. NFA is expressed as NFAVA since it allows for valuation adjustments (VA) arising from changes in the exchange rate of currencies other than the US dollar and changes in the price of gold.

12. This is especially true with a pass-through effect from exchange rates to prices of imports and then to domestic prices of more than $65 \%$ for an emerging country like Lebanon; see IMF (2006)

13. For instance, between 1996 and 2016, inflation averaged 4\% only, the exchange rate was stabilized at about 1,500 Lebanese pounds per 1 US dollar, and bank assets rose impressively from $\$ 25$ billion to $\$ 205$ billion.

14. To put this result in perspective, consider Japan. Over the past 30 years, Japan has experienced substantial increases in its real exchange rate with its nominal exchange rate against the US dollar appreciating from more than 220 Yens per 1 dollar to half of that now. Yet Japan's export performance and competitiveness have hardly been dented. Of course, Lebanon is not Japan, but still the analogy is highly instructive.

15. See Atallah and Ezzeddine (2017).

16. Technology's contribution is usually referred to as total factor productivity which captures qualitative growth; see Bolbol (2017) for an analysis of Lebanon's postwar growth accounting.

17. See Bolbol and Mouradian (2017); in 2016, the budget deficit was close to $\$ 5$ billion and public expenditures were $\$ 16$ billion out of which $34 \%$ went to the wage bill, $32 \%$ to interest payments, and at least $12 \%$ to transfers to EdL.

18. In the context of the traditional Swan Model, expenditure switching changes the composition of output, whereas expenditure changing alters the level of output, both in the aim of attaining external and internal balance. In terms of the model, Lebanon falls in the category of suffering from both internal and external imblances i.e. current account deficits and unemployment. For recent analysis of the Swan Model, see Temin and Vines (2013).

\section{REFERENCES}

Atallah, S. and Ezzeddine, N. 2017. Missed Opportunities in Lebanon's Industrial Sector. Featured Analysis, August. Lebanese Center for Policy Studies.

Azar, S., Bolbol, A. \& Mouradian, A. 2018. Private Savings in the Arab Countries: Empirical Analysis and Policy Implications. International Journal of Economics and Finance, 10(7): 10-22.

Blanchard, O. and Giavazzi, F. 2002. Current Account Deficits in the Euro Area: The End of the Feldstein-Horioka Puzzle? Brookings Papers on Economic Activity, 2.

Bolbol, A. 2017. A Note on Growth Accounting for the Post-War Lebanese Economy. Association of Banks in Lebanon Monthly Bulletin, May. 
Bolbol, A. and Mouradian, A. 2017. A Simple Note on the Productivity of Lebanon's Post-War Public Debt, 1993-2016. Association of Banks in Lebanon Monthly Bulletin, November.

Brissimis, S. et al. 2010. Current Account Determinants and External Sustainability in Periods of Structural Change. Working Paper Series No. 1243. European Central Bank.

Das, DK. 2016. Determinants of Current Account Imbalance in the Global Economy: A Dynamic Panel Analysis. Journal of Economic Structures, 5(8).

Harvey, A. C. 1976. Estimating Regression Models with Multiplicative Heteroscedasticity, Econometrica: Journal of the Econometric Society, 461-465.

Houthakker, H. and Magee, S. 1969. Income and Price Elasticities in World Trade". Review of Economics and Statistics, 51(2).

International Monetary Fund. 2006. Exchange Rates and Trade Balance Adjustments in Emerging Market Economies. IMF: Policy Development and Review Department.

Johansen, S. 1991. Estimation and Hypothesis Testing of Cointegrating Vectors in Gaussina Vector Autoregressive Models. Econometrica, 59: 1551-1580.

Johansen, S. 1995. Likelihood-Based Inference in Cointegrated Vector Autoregressive Models. Oxford University Press.

Johansen, S., and Juselius, K. 1990. Maximum Likelihood Estimation and Inferences on Cointegration-with Applications to the Demand for Money, Oxford Bulletin of Economics and Statistics, 52: 169-210.

Ketenci, N. 2014. The Effect of Global Financial Crisis on Trade Elasticities: Evidence from BRICS and Turkey. Journal of International and Global Economic Studies, 7(1): 6.

Obstfeld, M. and Rogoff, K. 1995. "The Intertemporal Approach to the Balance of Payments". In Grossman, G.M and Rogoff, K. (Eds), Handbook of International Economics, 3.

Ramsey, J. B. 1969. Tests for Specification Errors in Classical Linear Least Squares Regression Analysis. Journal of the Royal Statistical Society, Series B. 31(2): 350-371.

Senhadji, A. and Montenegro, C. 1999. Time Series Analysis of Export Demand Functions: A Cross-Country Analysis. IMF Staff Papers, 46: 3.

Temin P and Vines, D. 2013. The Leaderless Economy: Why the World Economic System Fell Apart and How to Fix It. Princeton University Press. 


$$
\begin{aligned}
& \text { ANNEX } \\
& \text { Appendix A: Derivation of the Marshall-Learner (M-L) } \\
& \text { REER: } \\
& \text { Let REER }=E=\left(e P / P^{*}\right) \\
& \text { Trade Balance }=T B \\
& \text { TB }=X\left(e P / P^{*}\right)-(M / e)\left(e P / P^{*}\right) \\
& T B=X E-(M / e) E \\
& \frac{\partial T B}{\partial E}=\frac{\partial X}{\partial E}+X-\frac{1}{e} \frac{\partial M}{\partial E}+\frac{M}{e^{2}} \frac{\partial e}{\partial E}-\frac{M}{e} \\
& \text { Multiply by }(E / X) \\
& \frac{\partial T B}{\partial E} \frac{E}{X}=\frac{\partial X}{\partial E} \frac{E}{X}+E-\frac{1}{e}\left(\frac{\partial M}{\partial E}\right)\left(\frac{E}{X}\right)+\frac{M}{e^{2}}\left(\frac{\partial e}{\partial E}\right)\left(\frac{E}{X}\right)-\frac{M E}{e X} \\
& \text { Since } \frac{\partial \mathrm{e}}{\partial \mathrm{E}}=\frac{1}{\partial E / \partial e}=\frac{1}{P / P^{*}}=\frac{P^{*}}{P} \\
& \text { And at equilibrium: } X=M / e \text { or that } M=e X \\
& \frac{\partial T B}{\partial E} \frac{E}{X}=\frac{\partial X}{\partial E} \frac{E}{X}-\left(\frac{\partial M}{\partial E}\right)\left(\frac{E}{M}\right)+\frac{M}{M e}\left(\frac{P^{*}}{P}\right)\left(\frac{e P}{P^{*}}\right) \\
& \frac{\partial T B}{\partial E} \frac{E}{X}=\frac{\partial X}{\partial E} \frac{E}{X}-\left(\frac{\partial M}{\partial E}\right)\left(\frac{E}{M}\right)+1 \\
& \text { Th }
\end{aligned}
$$

Appendix A: Derivation of the Marshall-Learner (M-L) Condition with Respect to

Given that $\frac{\partial X}{\partial E} \frac{E}{X}$ is the elasticity of $X$ with respect to $E=\mathcal{E}_{X}<0$

And that $\left(\frac{\partial M}{\partial E}\right)\left(\frac{E}{M}\right)$ is the elasticity of $M$ with respect to $E=\varepsilon_{M}>0$

Then $\frac{\partial T B}{\partial E}$ is negative if the sum of the absolute value of $\mathcal{E}_{X}$ and $\mathcal{E}_{M}>1$. In other words, an appreciation in the real effective exchange rate (higher $E$ ) will reduce the trade balance $T B$ if the Marshall-Lerner condition $\varepsilon_{X}+\mathcal{E}_{M}>1$ holds.

\section{Appendix B: Data Sources:}

Merchandise exports $\mathrm{X}$ and imports $\mathrm{M}$, the trade deficit TD, the current account $\mathrm{CA}$, and value adjusted net foreign assets NFAVA are from Banque du Liban (www.bdl.gov.lb) and IMF (www.imf.org); real effective exchange rates REER from Brugel (www.brugel.org); domestic output GDP and absorption expenditures ABS are from World Bank (www.worldbnak.org); weighted foreign income Yf is from UNCTAD (www.unctad.org); and international interest rates $r$ or yield on US 10-year government bonds is from FRED (www.stlouisfed.org). 